\title{
PENILAIAN KUALITAS CROSSWALK BERDASARKAN PEDESTRIAN ENVIRONMENT QUALITY INDEX (PEQI) (Studi Kasus : Jalan Pahlawan Kota Semarang)
}

\author{
Amanda Ristriana Pattisinai ${ }^{1)}$ dan Anita Susanti ${ }^{1)}$ \\ ${ }^{1)}$ Fakultas Teknik; Universitas Negeri Surabaya \\ Email: amandaristriana@unesa.ac.id
}

\begin{abstract}
Abstrak
Tujuan Penelitian ini adalah menjawab permasalahan bahwa Jalan Pahlawan harus melindungi keselamatan pejalan kaki pada persimpangan-persimpangan jalannya (crosswalk). Pada dasarnya semua pengguna moda angkutan umum ataupun kendaraan pribadi adalah pejalan kaki, oleh karena itu tersedianya fasilitas pejalan kaki yang memadai, aksesibilitas dan integrasi yang baik menuju angkutan umum, pusat kegiatan dan daerah tempat tinggal menjadi hal yang sangat penting dalam pengembangan konsep transportasi kota yang berkelanjutan. Dalam rangka menjadikan Kota Semarang sebagai kota nyaman pejalan kaki, Pemerintah Kota Semarang mewujudkan proyek perbaikan kualitas infranstruktur perkotaan dengan menata kawasan pusat kota dan di sejumlah ruas jalan protokol di Kota Semarang. Metode yang digunakan dalam pengkajian ini adalah Pendekatan PEQI (Pedestrian Environmental Quality Index) yang dapat mewadahi kebutuhan pengguna untuk beraktivitas didalamnya. Penelitian ini membuktikan bahwa pada Jalan Pahlawan belum mampu memberikan kualitas berstandar PEQI yaitu bahwa berjalan di sepanjang penggal jalur (crosswalk) tersebut akan menjadi pengalaman yang aman.
\end{abstract}

Kata kunci: jalur pejalan kaki; crosswalk; PEQI

\begin{abstract}
The Aim of this study is to answer the problem of Jalan Pahlawan must protect the safety of pedestrians at intersections path (crosswalk). Basically, all the modes of public transport or private vehicles are pedestrian, therefore the adequate pedestrian facilities, accessibility and very important in the concept of sustainable urban transportation. In order to make Semarang as pedestrian city, Semarang government launches the improvement of urban infrastructure quality by rearranging the central bussiness district area and many arteries at Semarang. The method used in this research is PEQI (Pedestrian Environmental Quality Index) that can accommodate the needs of the entire user. This study provoke that Jalan Pahlawan can not give the best performance of quality based on PEQI Standart that walking along the crosswalk should give a safe experience.
\end{abstract}

Keywords: pedestrian ways; crosswalk ; PEQI 


\section{PENDAHULUAN}

Pada dasarnya semua pengguna moda angkutan umum ataupun kendaraan pribadi adalah pejalan kaki, oleh karena itu tersedianya fasilitas pejalan kaki yang memadai, aksesibilitas dan integrasi yang baik menuju angkutan umum, pusat kegiatan dan daerah tempat tinggal menjadi hal yang sangat penting dalam pengembangan konsep transportasi kota yang berkelanjutan (GIZSUTIP, 2014). Lingkungan pejalan kaki juga mempengaruhi aktivitas masyarakat didalamnya, karena aktivitas pejalan kaki sangat bergantung pada bagaimana masyarakat menyadari penggunaan jalur pejalan kaki yang sesuai bagi nilai yang mereka bentuk (Kumar, 2007). Nilai ini akan memberikan keputusan apakah berjalan kaki dapat menjadi alternatif pilihan moda transportasi terbaik yang ramah lingkungan, ataukah tetap menggunakan kendaraan pribadi. Lingkungan berjalan kaki yang aman dan nyaman akan membentuk sense of place, sehingga pengalaman yang didapatkan dari kegiatan berjalan kaki akan menimbulkan keinginan untuk menjaga lingkungan (sense of belongin). Sementara lingkungan pejalan kaki yang tidak sesuai dengan nilai yang dibentuk oleh masyarakat akan ditinggalkan sebagai ruang kosong yang tidak termanfaatkan.

Levine dalam Moudon (1987) menyebutkan bahwa usaha untuk meningkatkan jalur kualitas jalur pejalan kaki juga dapat menghidupkan lingkungan perkotaan dan nilai-nilai sosial sosialnya. Fenomena yang berkembang bahwa polapola hubungan sosial-kultural pada masyarakat kita menyebabkan keinginan untuk menciptakan interaksi yang lebih intens pada perjalanannya. Kamino dalam Bibiano (2005) menyebutkan bahwa, kehadiran pedagang makanan jalanan adalah umum di kebanyakan jalur pejalan kaki dan proses interaksi ini menghasilkan hubungan yang hangat dan nyaman bagi masyarakat di Asia. Pada jalur pejalan kaki ini, timbul kontak sosial antar manusia yang bersifat universal, dengan ungkapan bervariasi seperti saling menyapa, berjabat tangan, ataupun menundukkan kepala yang merupakan hasil dari budaya lokal.

Berbeda dengan budaya barat yang memfungsikan jalur pejalan kaki sebagai alat pencapaian dengan kecepatan pejalam kaki tinggi, pejalan kaki di Indonesia terkenal lebih rentan terhadap kecelakaan. Pejalan kaki di Indonesia yang lebih mementingkan kontak sosial daripada fokus pada kegiatan berjalan kaki itu sendiri, menjadikan kelengahan pejalan kaki dalam menghadapi kondisi-kondisi yang membahayakan keselamatannya. Riset World Health Organization (www.walk21.com) menyatakan bahwa lebih dari $12 \%$ pengguna jalan yang menjadi korban kematian akibat kecelakaan di jalan raya adalah pejalan kaki. Jumlah pejalan kaki yang menjadi korban tentunya lebih banyak dari data statistik tersebut, karena kecelakaan pejalan kaki juga berakibat pada cedera tidak fatal seperti luka ringan dan luka berat, serta beberapa korban yang memerlukan perawatan dan pemulihan jangka panjang. Mayoritas (68\%) pejalan kaki mengalami kecelakaan pada saat menyeberang jalan (crosswalk) dan berada pada kondisi senja ataupun malam hari $(44,45 \%)$.

Penataan Jalan Pahlawan memang diperlukan karena animo masyarakat begitu besar untuk berkumpul dan melakukan kegiatan, dalam mengunjungi jalan yang terhubung jalan-jalan pusat kegiatan penting ini, seperti kegiatan mahasiswa Universitas Diponegoro di Jalan Imam Bardjo, aktivitas perkantoran pemerintah di Jalan Menteri Supeno, aktivitas pedagang makanan di Jalan Kusumawardhani, serta permukiman padat di belakang Kantor Polda Jateng terutama pada malam hari. Proyek ini telah mempercantik Jalan Pahlawan sehingga menjadi salah satu jalur pejalan kaki terbaik di Kota Semarang selain pada Jalan Pemuda dan Jalan Pandanaran (Kompas, 2009). Namun demikian, persyaratan sebuah tempat dapat dikatakan sebagai jalur pejalan kaki yang mengutamakan keselamatan pejalan kaki belum dapat dipenuhi oleh Jalan Pahlawan. Berdasarkan survei lapangan pada beberapa pengguna Jalan Pahlawan, pada saat ramai seringkali terjadi kecelakaan pada persimpangan jalan (crosswalk). Biasanya pejalan kaki terserempet pengguna kendaraan bermotor yang lewat di Jalan Pahlawan. Sehingga konsep pembangunan jalur pejalan kaki di Jalan Pahlawan ini menjadi dipertanyakan. Apakah Jalan Pahlawan telah melindungi keselamatan 
pejalan kaki pada persimpanganpersimpangan jalannya (crosswalk).

Pendekatan PEQI (Pedestrian

Environmental Quality Index) yang mendukung deklarasi ini, muncul sebagai pioner penilaian kualitas jalur pejalan kaki di berbagai kota-kota dunia seperti San Fransisco, Spanyol, Meksiko dan China. Pendekatan PEQI (Pedestrian Environmental Quality Index) dianggap mampu memberikan penilaian terhadap kualitas jalur pejalan kaki terhadap pilihan yang lebih luas terhadap penggunaa dan pemanfaatan yang beragam bagi pejalan kaki di Jalan Pahlawan. Pendekatan ini sangat berbeda bila dibandingkan dengan PLS (Pedestrian Level of Service) yang biasa digunakan untuk menilai suatu kawasan pejalan kaki dengan cakupan minimal 800 ruas jalan, sehingga tidak dapat digunakan untuk menilai kualitas persimpangan pada jalur pejalan kaki dengan lebih spesifik. Fokus PEQI adalah apakah fasilitas jalur pejalan kaki yang ada memadai, tidak hanya apa saja yang bisa ditingkatkan kualitasnya namun juga apakah berjalan di sepanjang jalur tersebut akan menjadi pengalaman yang yang menyenangkan. Dalam perkembangannya, PEQI juga memperhatikan faktor lingkungan yang ada yang mendukung penciptaan jalur pejalan kaki yang berkualitas sebagai ruang berkumpul bagi masyarakat, sehingga dalam laporan ini akan dibahas lebih lanjut mengenai kajian Jalan Pahlawan sebagai jalur pejalan kaki dengan menggunakan indikator PEQI.

Artetis setelah melewati filter zeolite dengan diameter zeolite $0,5 \mathrm{~mm}$ adalah ratarata $95,95 \%$. Zeolit teraktivasi dengan $\mathrm{NaCl}$ 2M mampu menurunkan kesadahan sebesar 73\% (Nurhayati, 2011).

Genteng termasuk dalam jenis gerabah. Gerabah merupakan salah satu jenis badan keramik yang dibuat dari semua jenis bahan tanah liat yang plastis dan mudah dibentuk dan dibakar pada suhu maksimum $1000^{\circ} \mathrm{C}$. Dilihat dari kandungan kimianya, tanah liat termasuk hidrosilikat alumina dan dalam keadaan murni mempunyai rumus: $\mathrm{Al}_{2} \mathrm{O}_{3} \quad 2 \mathrm{SiO}_{2} \quad 2 \mathrm{H}_{2} \mathrm{O}$. Keramik jenis ini struktur dan teksturnya sangat rapuh, kasar dan masih berpori. Sehingga bila digunakan sebagai media filter maka air bersih dapat keluar dari pori-pori pada bagian dasarnya. Filter tembikar memberikan efisiensi penurunan coliform sebesar $97,33 \%$ - 99,84\% dari jumlah bakteri coliform awal 1700 -9000 MPN/100 ml (Pratiwi, 2009).

Berdasarkan sifat-sifat media tersebut peneliti ingin melakukan penelitian tentang pengaruh media filtrasi terhadap kualitas air sumur gali. Tujuan dari penelitian ini adalah untuk mengetahui pengaruh kombinasi media filtrasi (zeolit-pecahan genteng dan karbon aktif-pecahan genteng) terhadap efisiensi penurunan $\mathrm{CaCO}_{3}$ dan bakteri coliform pada air sumur gali. Diharapkan dari hasil penelitian ini dapat memberikan wawasan kepada masyarakat tentang alternatif teknologi yang sederhana, mudah pengoperasianya dan murah, untuk menurunkan konsentrasi kesadahan dan kandungan bakteri coliform pada air tanah.

\section{METODE}

Riset keselamatan berjalan kaki pada bagian crosswalk berdasarkan Pedestrian Environment Quality Index (PEQI), menggunakan pendekatan kuantitatif untuk mengetahui kualitas jalur pejalan kaki dengan mempertimbangkan beberapa kriteria. Pendekatan PEQI (Pedestrian Environmental Quality Index) digunakan dalam penelitian ini untuk dapat penilaian terhadap kualitas jalur pejalan kaki terhadap pilihan yang lebih luas terhadap penggunaa dan pemanfaatan yang beragam bagi pejalan kaki di Jalan Pahlawan.

Pendekatan PEQI jika dibandingkan dengan pendekatan lain memiliki keunggulan pada penilaian yang lebih spesifik dan detail mengenai kebutuhan lingkungan pejalan kaki, baik pada segmen maupun persimpangannya. Pendekatan ini dianggap cocok untuk menilai keselamatan berjalan kaki pada bagian crosswalk di Jalan Pahlawan. PEQI dalam menilai kualitas crosswalk Jalan Pahlawan harus disesuaikan dengan karakteristik jalur pejalan kaki di Indonesia terlebih dahulu. Kemudian dilakukan perhitungan untuk untuk menentukan kelas kualitas crosswalk jalur pejalan kaki di Koridor Jalan Pahlawan Semarang sebagai berikut.

Kualitas Persimpangan $=$ 
(Total nilai pada perhitungan persimpangan jalan - nilai min) $x \frac{100}{(\text { nilai max }- \text { nilai } \min )}$

Selanjutnya setelah memperoleh jumlah kelas, maka ditentukan interval kelas.
Sehingga berdasarkan perhitungan, nantinya hasil skoring tersebut akan menghasilkan lima kelas kualitas pejalan kaki sebagai berikut.

Tabel 1. Klasifikasi Kelas Kualitas Jalur Pejalan Kaki

\begin{tabular}{ccl}
\hline Kelas & Skor & \multicolumn{1}{c}{ Keterangan } \\
\hline I & $81-100$ & Lingkungan pejalan kaki yang tidak cocok untuk pejalan kaki \\
II & $61-80$ & Kualitas jalur pejalan kaki yang buruk \\
III & $41-60$ & Kualitas jalur pejalan kaki basis/ dasar \\
IV & $21-40$ & Kualitas jalur pejalan kaki yang dapat diterima/ reasonable \\
V & $1-20$ & Kualitas jalur pejalan kaki yang ideal \\
\hline \multicolumn{2}{l}{ Sumber : Pedestrian Environement Quality Index, 2009 }
\end{tabular}

Dalam penelitian ini pengambilan sampel penelitian dilakukan dengan menggunakan metode sampling random (probability sampling). Pemilihan metode ini dianggap tepat digunakan dalam penelitian yang jumlah populasinya belum diketahui disebabkan jumlahnya yang selalu berubahubah setiap tahunnya (tidak stabil). Adapun jenis metode pengambilan sampel yang digunakan adalah teknik sampling area (area sampling). Teknik sampling area dianggap tepat pada populasi geografis yang tidak diketahui, dicapai dengan memperlakukan beberapa responden dalam area lokal sebagai bagian-bagian kluster sebagai sampel penelitian. Keuntungan menggunakan teknik ini ialah murah, cepat, dan mudah (Usman dan Akbar, 2008).

Penelitian ini akan dibagi berdasarkan beberapa segmen penggal jalan pada Jalan Pahlawan Semarang. Penjelasan pembagian segmen penilaian persimpangan dapat dilihat pada gambar 1 .

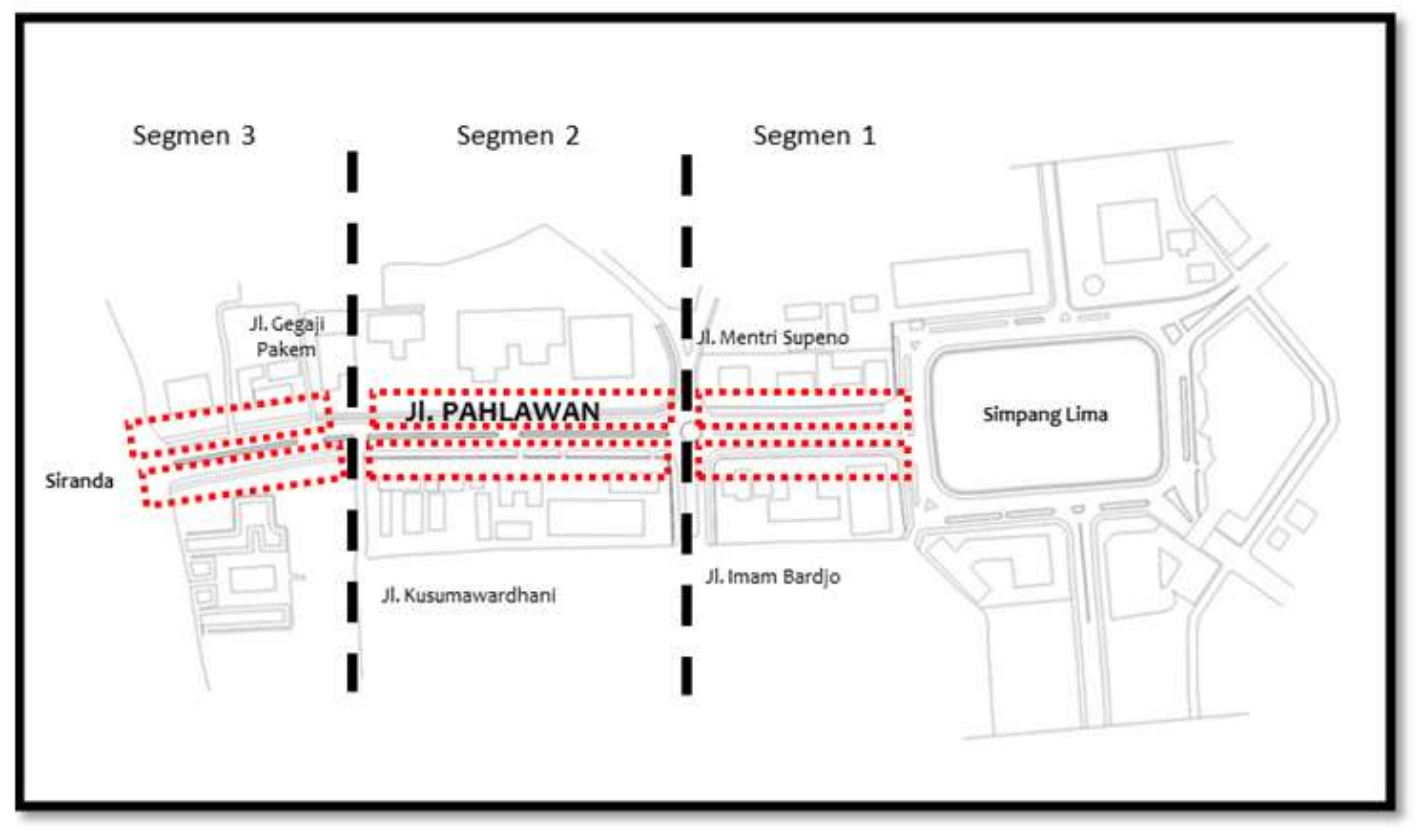

Gambar 1. Pembagian Segmen Wilayah Penelitian

\section{HASIL DAN PEMBAHASAN}

Hasil analisis laboratorium air sumur gali sebelum dan setelah treatment disajikan dalam Tabel 1. Dari Tabel 1 menunjukkan hasil konsentrasi $\mathrm{CaCO}_{3}$ dan bakteri coliform sebelum treatment yaitu sebesar $748 \mathrm{mg} / \mathrm{l}$ dan $480 \mathrm{MPN} / 100 \mathrm{ml}$, bila dibandingkan dengan baku mutu untuk 
parameter $\mathrm{CaCO}_{3}$ dan bakteri coliform menurut Peremenkes no. 416 tahun 1990 sebesar $500 \mathrm{mg} / \mathrm{l}$ dan $<50 \mathrm{MPN} / 100 \mathrm{ml}$ maka parameter tersebut belum memenuhi baku mutu sehingga tidak aman untuk digunakan sebagai air bersih. Oleh karena itu air sumur tersebut perlu dilakukan pengolahan untuk menghasilkan air bersih yang sesuai baku mutu air bersih terutama untuk parameter $\mathrm{CaCO}_{3}$ dan bakteri coliform menurut Permenkes no. 416 tahun 1990.
Setelah difiltrasi baik yang menggunakan media pecahan genteng-zeolit maupun media pecahan genteng-karbon aktif untuk parameter $\mathrm{CaCO}_{3}$ sudah memenuhi baku mutu yaitu $143 \mathrm{mg} / \mathrm{l}$ pada filter 1 (pecahan genten-zeolit) dan 35mg/1 pada filter 2 (pecahan genteng-karbon aktif). Sedangkan untuk parameter bakteri coliform kedua filter belum memenuhi baku mutu yakni 200 MPN/100ml pada filter 1 (pecahan genten-zeolit) dan $50 \mathrm{MPN} / 100 \mathrm{ml}$ pada filter 2 (pecahan genteng-karbon aktif).

Tabel 1. Hasil Analisis Laboratorium Air Sumur Gali Sebelum dan Setelah Treatment

\begin{tabular}{clcccc}
\hline No & Filter & $\begin{array}{c}\text { Pengambilan } \\
\text { Sampel (Hari) }\end{array}$ & $\begin{array}{c}\mathbf{C a C O}_{3} \\
\mathbf{( m g / l )}\end{array}$ & $\begin{array}{c}\text { Bakteri } \\
\text { Coliform } \\
\text { (MPN/100ml) }\end{array}$ & pH \\
\hline 1 & Pecahan & 0 (mula-mula) & 748 & 480 & 6,9 \\
& Genteng- & 2 & 150 & 315 & 6,9 \\
& Zeolit & 4 & 143 & 270 & 6,9 \\
& & 6 & 159 & 200 & 7,0 \\
2 & Pecahan & 0 (mula-mula) & 748 & 480 & 7,0 \\
& Genteng- & 2 & 41 & 111 & 7,0 \\
& Karbon & 4 & 35 & 89 & 7,0 \\
& Aktif & 6 & 48 & 50 & 7,1 \\
\hline
\end{tabular}

\section{Pengaruh Kombinasi Media Filtrasi \\ Terhadap Efisiensi Penurunan $\mathrm{CaCO}_{3}$}

Efisiensi penurunan $\mathrm{CaCO}_{3}$ setelah melalui filtrasi menggunakan media pecahan genteng-zeolit dan pecahan genteng-karbon aktif ditunjukkan pada Gambar 2. Gambar 2 menunjukkan bahwa kedua media filtrasi dapat menurunkan $\mathrm{CaCO}_{3}$ dengan efisiensi yang baik. Hal ini terjadi karena pada filter 1 proses penghilangan $\mathrm{CaCO}_{3}$ menggunakan media zeolite terjadi karena reaksi pertukaran ion. Pada saat sebelum proses seluruh lapisan unggun akan ditempati oleh ion hydrogen $\left(\mathrm{H}^{+}\right)$ion $\mathrm{H}^{+}$terbentuk pada saat aktivasi zeolit menggunakan $\mathrm{HCl} 1 \mathrm{~N}$ dimana ion aluminium pada zeolit digantikan oleh ion $\mathrm{H}^{+}$dari $\mathrm{HCl}$. Tahap berikutnya ion magnesium masuk menempati unggun menggantikan ion hydrogen, setelah itu ion kalsium masuk menempati posisi diatas magnesium dan ion hydrogen akan keluar bersama aliran air. Ion kalsium menempati posisi paling atas karena memiliki nilai afinitas paling besar kemudian diikuti magnesium dan terakhir hydrogen. Jika reaksi ini berlangsung terus menerus maka seluruh media akan terisi ion kalsium dan magnesium. Pecahan genteng pada kedua filter berfungsi sebagai pembantu proses penyerapan $\mathrm{Ca}^{2+}$. Pada filter 2 terjadi proses adsorbsi oleh karbon aktif. Proses adsorbsi dapat digambarkan sebagai proses dimana molekul meninggalkan larutan dan menempel pada permukaan zat akibat ikatan kimia dan fisika. Dalam filtrasi ini ion $\mathrm{Ca}^{2+}$ akan diserap kedalam pori-pori karbon aktif dan terakumulasi pada pori karbon aktif. Pecahan genteng termasuk dalam gerabah lunak yang memiliki sifat porous. Sifat porous ini yang memungkinkan air merembes melewati por-pori media dan ion $\mathrm{Ca}^{2+}$ akan tertahan pada pori-pori media pecahan genteng.

Selain itu penurunan $\mathrm{CaCO}_{3}$ disebabkan debit pada masing-masing filter adalah $1 \mathrm{~L} / \mathrm{jam}$ dengan debit tersebut maka di peroleh waktu tinggal air pada filter selama 6,3 jam. Lama kontak air dengan media inilah yang menyebabkan efisiensi yang dicapai tinggi. Karena semakin lama waktu kontak maka semakin lama proses 
adsorbsi ataupun pertukaran ion yang terjadi sehingga semakin banyak $\mathrm{Ca}^{2+}$ yang diserap. $\mathrm{pH}$ yang netral pada kedua filter juga menambah efisiensi kerja filter, $\mathrm{pH}$ yang baik dalam mengadsorpsi $\mathrm{Ca}^{2+}$ adalah $\mathrm{pH}$ dalam range 6-8 (Dinora, 2013).

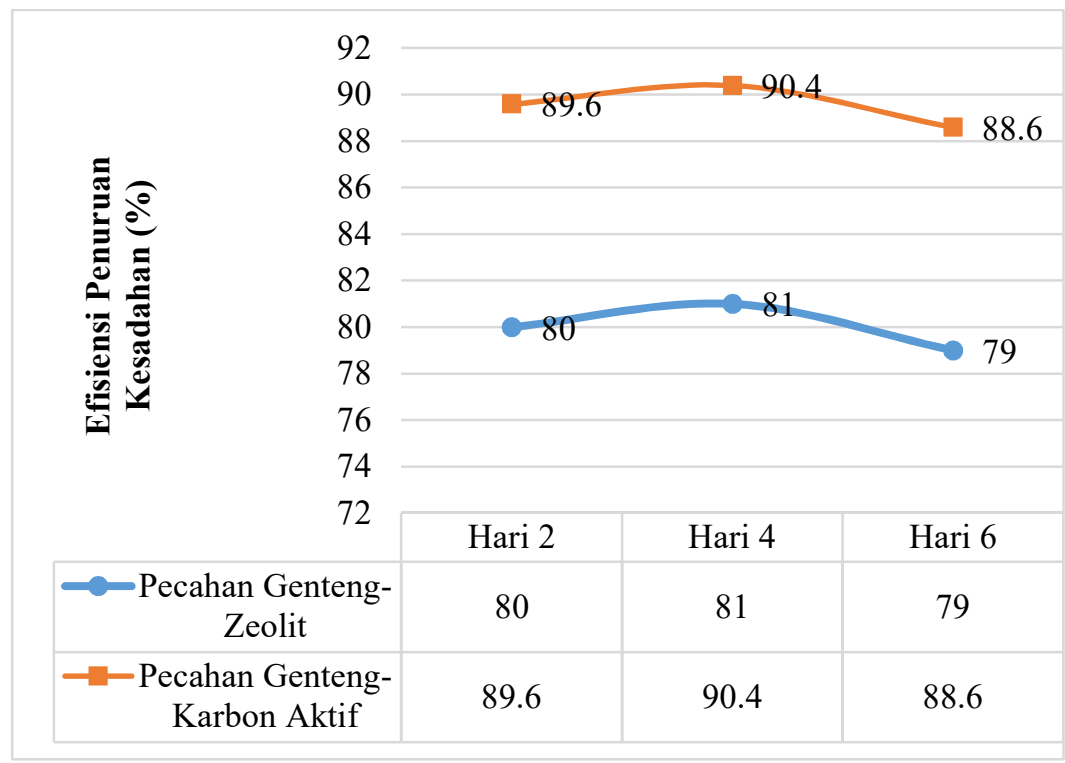

Gambar 2. Grafik Efisiensi Penurunan $\mathrm{CaCO}_{3}$

Jika dilihat dari Gambar 2, efisiensi penurunan $\mathrm{CaCO}_{3}$ tertinggi terjadi pada filter 2 (pecahan genteng-karbon aktif) yakni sebesar 90,4\% sedangkan pada filter 1 (pecahan genteng-zeolit) hanya $81 \%$. Hal ini disebabkan karena adanya perbedaan ukuran partikel. Pada penelitian ini Karbon aktif memiliki ukuran partikel sebesar $0,59 \mathrm{~mm}$ dan zeolite sebesar $1 \mathrm{~mm}$. Ukuran partikel yang kecil mengakibatkan luas permukaan semakin besar sehingga semakin banyak bagian zat yang saling bertumbukan yang menghasilkan perubahan. Sehingga semakin luas permukaan zat maka semakin cepat pula laju reaksi (Widjajanti, 2007). Ukuran partikel yang kecil menyebabkan semakin luas permukaan zat sehingga kemampuan untuk mengadsorbsi semakin meningkat (Alfiany, 2013).

Gambar 2 menunjukkan efisiensi kesadahan menurun pada hari ke- 6 dengan efisiensi terendah sebesar $79 \%$ pada filter 1 (pecahan genteng-zeolit) dan $88,6 \%$ pada filter 2 (pecahan genteng-karbon aktif). Walaupun terjadi penurunan efisiensi pada kedua filter namun penurunan efisiensi yang terjadi belum menimbulkan nilai yang berarti karena konsentrasi $\mathrm{CaCO}_{3}$ masih memenuhi baku mutu air bersih. Penurunan efisiensi merupakan indikator bahwa media pada filter telah mengalami kejenuhan, sehingga kemapuan untuk mengadsorbsi ataupun menukar ion menurun sehingga perlu adanya backwashing.

\section{Pengaruh Kombinasi Media Filtrasi Terhadap Efisiensi Penurunan Bakteri Coliform}

Pengaruh kombinasi media filtrasi pecahan genteng-zeolit dan pecahan genteng-karbon aktif terhadap efisiensi penurunan bakteri coliform ditunjukkan pada Gambar 3. Gambar 3 menunjukkan bahwa kedua media filtrasi dapat menurunkan bakteri colifrom dengan efisiensi yang baik. Hal ini terjadi karena, pada filter 2 proses penurunan bakteri coliform akibat dari proses adsorbsi fisik oleh karbon aktif. Menurut Saryati (2002) pori-pori karbon aktif mampu mengambil bakteri dari air. Karbon memiliki volume pori yang besar sehingga banyak mengandung kapilerkapiler yang yang halus, sehingga zat yang teradsorpsi akan terpenetrasi pada sela-sela kapiler karbon aktif jika larutan itu membasahinya. Dalam hal ini bakteri coliform akan terjebak pada kapiler-kapiler karbon aktif. Pada filter 1 (pecahan gentengzeolit) bakteri coliform ditahan pada lapisan filter yang disebabkan ukuran pori filter dan kombinasi ukuran pori. bakteri akan membentuk lapisan biofilm. Biofilm terdiri 
dari sel-sel mikroorganisme yang melekat erat ke suatu permukaan sehingga berada dalam keadaan diam, tidak mudah lepas atau berpindah tempat (irreversible). Bakteri yang menempel pada suatu permukaan cenderung membentuk agregat dimana sel tersebut saling melekat satu sama lain dan membentuk suatu matriks polimer yang disebut biofilm. Pembentukan biofilm menunjukkan fase kehidupan bakteri yang konstan, fase ini disebut fase stasioner. Setelah fase stasioner selanjutnya bakteri akan mengalami fase kematian dimana populasi bakteri akan menurun jumlanya karena kekurangan nutrisi. Pada fase kematian bakteri akan membentuk lumpur halus, lumpur halus inilah yang akan tertahan pada pori-pori media. Pecahan genteng juga memiliki sifat porous sehingga memungkinkan untuk menahan bakteri pada lapisan filternya. Lumpur halus juga akan ditahan oleh kombinasi ukuran pori pada pecahan genteng.

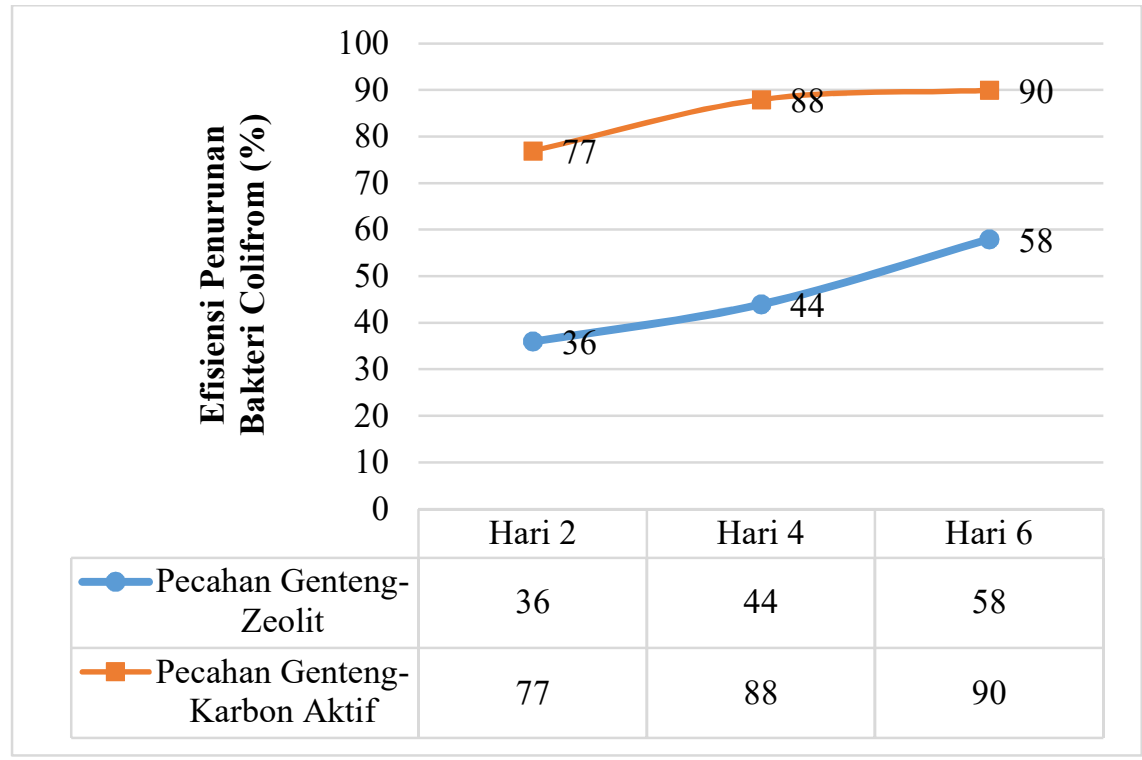

Gambar 3. Grafik Efisiensi Penurunan Bakteri Coliform

Efisiensi penurunan bakteri coliform mengalami kestabilan kenaikan pada mulai hari ke2 sampai hari ke-6 hal ini dikarenakan debit yang dialirkan pada kedua filter sebesar 1 1/jam, menghasilkan kecepatan filtrasi sebesar $0,1 \mathrm{~m} / \mathrm{jam}$ pada kecepatan filtrasi yang lambat ini maka proses desinfeksi oleh media filter akan lebih efektif. Kestabilan kenaikan efisiensi disebabkan kerena semakin lama waktu inkubasi substrat pada media maka semakin besar pula lapisan biofilm yang dibentuk sehingga bakteri akan lebih cepat mengalami fasa kematian.

Jika dilihat pada Gambar 3, menunjukkan efisiensi terbesar penurunan bakteri coliform terjadi pada filter 2 (pecahan genteng-karbon aktif) mencapai $90 \%$ sedangkan pada filter 1 (pecahangenteng-zeolit) efisiensi hanya mencapai $58 \%$. Hal ini disebabkan karena perbedaan ukuran partikel pada media karbon aktif dan zeolite, dimana pada penelitian ini karbon aktif memiliki ukuran partikel sebesar $0,59 \mathrm{~mm}$ sedangkan zeolit sebesar $1 \mathrm{~mm}$. Ukuran partikel yang kecil menyebabkan semakin luas permukaan zat. Dengan luas pemukaan yang semakin luas menyebabkan semakin banyak mengandung kapilerkapiler yang yang halus, sehingga zat yang teradsorpsi semakin banyak. Media filter jenis arang bekerja lebih baik dibandingkan kerikil dalam menurunkan bakteri total coliform (Suryanti, 2012). Selain itu dengan berkurangnya konsentrasi kesadahan $\left(\mathrm{CaCO}_{3}\right)$ maka berkurang pula kandungan $\mathrm{Ca}^{2+}$ dan $\mathrm{Mg}^{2+}$. $\mathrm{Ca}$ dan $\mathrm{Mg}$ merupakan sumber nutrisi untuk pertumbuhan bakteri. Dengan berkurangnya kandungan $\mathrm{Ca}^{2+}$ dan $\mathrm{Mg}^{2+}$ pada air maka berkurang pula sumber nutrisi untuk pertumbuhan bakteri coliform sehingga bakteri coliform akan lebih cepat mengalami fasa kematian. Filter 2 (pecahan genteng-karbon aktif) menurunkan $\mathrm{CaCO}_{3}$ lebih besar dari pada filter 1(pecahan genteng-zeolit) sehingga konsentrasi bakteri 
coliform lebih banyak diturunkan pada filter 2(pecahan genteng-karbon aktif). Walaupun efisiensi ke dua filter naik secara signifikan namun belum memenuhi baku mutu air bersih.

\section{KESIMPULAN}

Dari hasil penelitian yang dilakukan diperoleh kesimpulan bahwa konsentrasi $\mathrm{CaCO}_{3}$ dan bakteri coliform sebelum treatment masing-masing adalah sebesar 748 $\mathrm{mg} / \mathrm{l}$ dan $480 \mathrm{MPN} / 100 \mathrm{ml}$, konsentrasi ini belum memenuhi baku mutu berdasarkan Peremenkes no. 416 tahun 1990. Dan setelah treatment pada filter 1 (pecahan gentengzeolit) adalah $143 \mathrm{mg} / \mathrm{l}$ dan 200 MPN/100ml, pada filter 2 (pecahan gentengkarbon aktif) adalah $35 \mathrm{mg} / 1$ dan 50 MPN/100ml. Setelah treatment parameter $\mathrm{CaCO}_{3}$ pada ke dua filter telah memenuhi baku mutu, sedangkan untuk parameter bakteri coliform belum memenuhi baku mutu. Filter dengan kombinasi media pecahan genteng-zeolit dapat menurunkan $\mathrm{CaCO}_{3}$ dengan efisiensi mencapai $81 \%$ dan bakteri coliform dengan efisiensi mencapai $58 \%$. Filter dengan kombinasi media pecahan genteng-karbon aktif dapat menurunkan $\mathrm{CaCO}_{3}$ dengan efisiensi mencapai $90,4 \%$ dan bakteri coliform dengan efisiensi mencapai $90 \%$. Kombinasi media pecahan genteng-karbon aktif menghasilkan efektifitas penurunan $\mathrm{CaCO}_{3}$ dan bakteri coliform yang lebih besar dibandingkan dengan media pecahan genteng-zeolit.

Perlu adanya pengolahan lebih lanjut seperti penambahan desinfektan atau penambahan waktu operasional filtrasi untuk menurunkan bakteri coliform, karena selama 6 hari proses filtrasi, konsentrasi bakteri coliform belum memenuhi baku mutu.

\section{Ucapan Terima Kasih}

Ucapan terima kasih ditujukan kepada Universitas Negeri Surabaya yang telah mendukung penelitian dan memberikan fasilitas laboratorium.

\section{DAFTAR PUSTAKA}

Alfiany, dkk. 2013. Kajian Penggunaan Arang Aktif Tongkol Jagung Sebagai Adsorben Logam Pb Dengan Beberapa Aktivator Asam. Jurnal Natural Science Vol. 2 (3) : 75-86 ISSN: 2338-0950. Fakultas MIPA, Universitas Tadulako

Andi Taufan. 2008. Pengujian Alat Pendingin Adsorpsi Dua Adsorber Dengan Menggunakan Methanol 250ml Sebagai Refrigeran, Fakultas Teknik, Program Studi Teknik Mesin, Universitas Indonesia: Depok.

Dinora. 2013. Penurunan Kandungan Zat Kapur dalam Air Tanah dengan Menggunakan Media Zeolit Alam dan Karbon Aktif Menjadi Air Bersih. Jurusan Teknik Lingkungan, FTSP, Institut Teknologi Sepuluh Nopember (ITS). JURNAL TEKNIK POMITS Vol. 2, No. 2, (2013) ISSN: 2337-3539

Edahwati, Luluk. 2013. Kombinasi Proses Aerasi, Adsorpsi, Dan Filtrasi Pada Pengolahan Air Limbah Industri Perikanan. Jurnal Ilmiah Teknik Lingkungan Vol.1 No. 2. UPN "Veteran". Surabaya

Ganefati, S.P. dkk. 2005. Pengolahan Air Minum Sumur Gali Untuk Rumah Tangga Secara Aerasi, Filtrasi Dan Desinfeksi. Yogyakarta: Jurnal Teknik Lingkungan, P3TLBPPT.6(1):262-267.

Nurhayati Indah. 2011. Sistem Distribusi Air Minum. Surabaya: Universitas PGRI Adi Buana Surabaya.

Nurullita,dkk. 2010. Pengaruh Lama Kontak Karbon Aktif Sebagai Media Filter Terhadap Persentase Penurunan Kesadahan $\mathrm{CaCO}_{3}$ Air Sumur Artetis. Fakultas Kesehatan Masyarakat Univeritas Muhammadiyah Semarang. Semarang: Jurnal kesehatan masyarakat Indonesia vol.6 no.1 tahun 2010.

Pratiwi, L. 2009. Analisis Saringan Tembikar Berlapis Larutan Perak Nitrat Terhadap Penurunan Bakteri Coliform dan Kekeruhan. Jurusan Teknik Lingkungan-FTSP ITS Surabaya 
Saryati, dkk. (2002). Komposit Tawas Arang Aktif Zeolit Untuk Memperbaiki Kualitas Air. Jurnal Sains Materi Indonesia Volume 4 No. 1 hal : 9 - 15 ISSN : 1411-1098. Tangerang: Puslitbang Iptek Bahan (P3IB) - Batan.

Suryanti. 2012. Studi Penurunan Kandungan Total Coliform Dengan Menggunakan Kombinasi Vertical Flow Roughing Filter (VRF) Dan Horizontal Flow Roughing Filter (HRF) Pada Air Buangan Domestik Artifisial. Program Studi Teknik Lingkungan, Fakultas Teknik, Universitas Diponegoro Semarang

Sutrisno Joko. 2006. Pengantar Satuan Operasi. Surabaya: Universitas PGRI Adi Buana Surabaya.

Widjajanti Endang LFX. 2007. Kinetika Kimia. Jurusan Pendidikan Kimia, FMIPA UNY. 